\title{
Flowering and Fruiting Times on Four Species of Annona (Annonaceae)
} in Purwodadi Botanic Garden

Dewi Ayu Lestari ${ }^{*}$, Siti Sofiah ${ }^{1}$

${ }^{1}$ Purwodadi Botanic Garden, Indonesian Institute of Sciences, Pasuruan, Indonesia

\section{ABSTRACT}

Annona is a genus belongs to Annonaceae family, consisting of numerous species that produce edible fruit. Four species namely $A$. glabra, A. montana, $A$. muricata and $A$. squamosa collections of Purwodadi Botanic Garden were recorded for its flowering and fruiting times, since November 2010 to April 2013. The data were scored and complemented with climate data (temperature, rainfall intensity, humidity) then analyzed using multiple linear regression analysis. The result showed that humidity was the most affected climate factors on the flow ering and fruiting times of those species. Specifically, rainfall intensity $(0-550 \mathrm{~mm})$ affected to Annona muricata, temperature $\left(25,56-28,33^{\circ} \mathrm{C}\right)$ and humidity $(66,83-85,02 \%)$ to Annona squamosa, and humidity to A. glabra (71,62-85,02\%) and $A$. montana (71,62 to $82,94 \%)$ as well. Flowering time of $A$. glabra occurs three times a year in wet and dry, and fruiting occurs twice a year in the same month. Annona muricata is flowering throughout the year and fruiting twice a year in wet. A. montana and $A$. squamosa recorded one a year during the wet month.

Keywords: Annona, climatic factor, flowering and fruiting times, Purwodadi Botanic Garden

\section{INTRODUCTION}

Annona is a genus belongs to Annonaceae family, consisting of numerous species that produce edible fruit. Annona is economically important in many countries of Africa and Asia as well as in South, North and Central America. The name annona derives from the Latin "annual harvest" and indicates their typical annual producing cycle. In general, the annona are shrubs or small trees, with height from 5,0 to $7,5 \mathrm{~m}$; they are erect or somewhat spreading and possess greybrown bark, often rough and corrugated. The characteristic feature of the genus, Annonais fruit is a syncarpium, formed by the amalgamation of many pistils and the fleshy receptacle. The hermaphrodite flowers are yellowish with 3 to 6 tepals and numerous stamens and pistils. The genus Annona has about 120 species namely $A$. squamosa L., A. cherimola Mill., A. reticulata L., A. muricata L., A. dioica among others. Its was found in Central and South America, Africa, Asia, and Australia [1-3]. Examples of edible Annona fruits are A. cherimola Mill., A. diversifolia Saff., A. montana Macfad, A. muricata L., A. purpurea Moc. Et Sesse, $A$.

\footnotetext{
*Corresponding author:

Dewi Ayu Lestari

Purwodadi Botanic Garden, Indonesian Institute of Sciences

Pasuruan, Indonesia

E-mail: chunyang_dee@yahoo.co.id
}

reticulata L., $A$. squamosa $\mathrm{L}$. and $A$. squamosa x $A$. cherimola [1]. Purwodadi Botanic Garden as one of the ex-situ conservation institution have a plant collection from genus Annona, namely $A$. glabra, $A$. montana, $A$. muricata and $A$. squamosa. The fourth species are periodically of flowering and fruiting. A plant has different behavior on the pattern of flowering and fruiting, but begins with the appearance of flower buds and ends with fruit ripening [4].

Climate elements affect the phenology of plants such as the vegetative phase and reproductive components. This effect can be minor or major. It is suggested that climatic factors not be directly responsible for triggering and synchronization of phenological events $[5,6]$. Also to climatic variables, flowering, and fruiting phenology also affected by biotic factors. Plants as part of a community in a habitat will be affected by the elements around it, through competition, herbivory, pollination and seed dispersal [7].

Time fruiting and flowering plants are correlated with climatic conditions that will be best for offspring survival in its habitat. This is one of the plants adaptations. In tropical regions with a pronounced dry season receives more annual sunlight available for photosynthesis compared with temperate climate region. Therefore simply be the consequence of selection for the same favorable time for reproduction about climate. 
Fruiting often occurs at the beginning of the rainy season, which presumably minimizes the exposure of seeds to seed predators. Its also provides maximum time for seedlings to develop the root systems needed to survive drought during their first dry season [8]. The phenological patterns are recorded about climatic 'triggers' (proximate factors) and plant-animal interactions or ultimate factors [9]. The aim of this study was to determine the climatic factors that most affect on Annona flowering and fruiting times in Purwodadi Botanic Garden, accompanied by flowering and fruiting times of four species.

\section{MATERIALS AND METHODS}

The research was conducted in Purwodadi Botanic Gardens on Annona collection (A. glabra, A. montana, A. muricata and $A$. squamosa) in vak XVIII.C. dan XIX.B.I., since November 2010 to April 2013.

Each phenological characteristic was observed from the whole canopy of selected trees. Some characters plant observed as follow; immature leaves, mature leaves, red or yellow leaves, flower buds, flowering, young fruits, immature fruits, and ripe fruits. Observations were made once a week. Another variable was observed is climate data, include temperature $\left({ }^{\circ} \mathrm{C}\right)$, humidity (\%) and rainfall intensity ( $\mathrm{mm})$.

Data were analyzed using multiple linear regression analysis with MINITAB 14 statistic program, resulting models to determine the most affected climate factors on the flowering and fruiting times of those species.

Then data were determined by the phenomena of phenological records. Phenomena under the following criteria were quantitatively described by the phenological records (Table 1) [10]. Its namely, vegetative growth, which consist of evergreens and deciduousness, patterns of stem elongation and seasonal synchronism of stem elongation. The second one is reproductive growth, which consist of flowering frequency, flowering period, the seasonal synchronism of flowering and fruiting.

\section{RESULTS AND DISCUSSION}

The result showed that humidity was the most affected climate factors on the flowering and fruiting times of those species. The models of each species were listed in Table 2. For A. glabra, each derivation of $1^{\circ} \mathrm{C}$ temperature will increase immature leaves as much as $6,05 \%$. Each derivation of $1 \mathrm{~mm}$ rainfall intensity will increase immature leaves as much as $0,0217 \%$. The derivation of $1 \%$ moisture will reduce immature leaves as much as $1,05 \%$ of $A$. glabra. The interpretation model is increasing of each humidity $1^{\circ} \mathrm{C}$ temperature will reduce yellow leaves as much as $1,05 \%$. Then, increasing $1 \mathrm{~mm}$ rainfall intensity will increase yellow leaves as much as $0,0036 \%$. The other one is enhancement $1 \%$ humidity will reduce yellow leaves as much as 1,13 . The humidity affected to $A$. glabra as much as 71,62 to $85,02 \%$. Flowering time of $A$. glabra occurs three times a year in wet and dry, and fruiting twice a year in the same month. These species include weeds that need water and humidity are sufficient to germinate and produce a flower or fruit [11].

Humidity being the most influential factor on flowering and fruiting time in $A$. montana as much as 71,62 to $82,94 \%$. The increasing of each $1^{\circ} \mathrm{C}$ temperature will reduce flower buds and flowering as much as $0,182 \%$. Each increase of $1 \mathrm{~mm}$ rainfall intensity will reduce flower buds and flowering as much as $0,00027 \%$. The increasing of each $1 \%$ humidity will reduce flower buds and flowering as much as 0,139\%. The increasing of each $1^{\circ} \mathrm{C}$ temperature will increase young fruit as much as $0,03 \%$. Increasing each of 1 $\mathrm{mm}$ of rainfall intensity will increase young fruit as much as $0,0010 \%$. Then, each increase of $1 \%$ humidity will reduce young fruit as much as $0,393 \%$. A. montana has flowering and fruiting time recorded one year during the wet month.

Rainfall intensity becomes the most influential factor to flowering and fruiting time on $A$. muricata with interval $0-550 \mathrm{~mm}$. A. muricata flowering throughout the year and fruiting twice a year in a wet month. There are no climate factors that influence the emergence of flower buds, flowering, and ripe fruit. The seasonality of rainfall might influence the evolution of flowering and fruiting in tropical forests [12]. A. muricata can be well adapted to the area that has heavy rain (up to $4.000 \mathrm{~mm} /$ year) and also intolerant to an area

Table 1. The proportion of shoots in the phenological cate gories [10].

\begin{tabular}{|c|c|c|}
\hline Ranks & Phenological categories & Means \\
\hline 1 & Nothing $(0 \%)$ & $\begin{array}{l}\text { There were no shoots on vegetative and } \\
\text { generative growth in whole canopy (no shoots at }\end{array}$ \\
\hline 2 & Rare $(30 \%)$ & $\begin{array}{l}\text { all) } \\
\text { Abundance of shoot on vegetative and generative }\end{array}$ \\
\hline 3 & Moderate $(60 \%)$ & $\begin{array}{l}\text { growth less than } 30 \% \text { in whole canopy } \\
\text { Abundance of shoot on vegetative and generative }\end{array}$ \\
\hline 4 & $\begin{array}{l}\text { Moderately abundant } \\
(80 \%)\end{array}$ & $\begin{array}{l}\text { growth less than } 60 \% \text { in whole canopy } \\
\text { Abundance of shoot on vegetative and generative }\end{array}$ \\
\hline 5 & Abundant $(80 \%)$ & $\begin{array}{l}\text { growth less than } 80 \% \text { in whole canopy } \\
\text { Abundance of shoot on vegetative and generative } \\
\text { growth more than } 30 \% \text { in whole canopy }\end{array}$ \\
\hline
\end{tabular}


Table 2. Models of phenological characteristics of four species of Annona collection.

\begin{tabular}{|c|c|c|}
\hline Species & Phenological characteristics & Models \\
\hline \multirow{8}{*}{ A. glabra } & Immature leaves & $-69,2+6,05$ temperature $+0,0217$ rainfall intensity $-1,05$ humidity (all factors) \\
\hline & Mature leaves & $88,0-0,000000$ temperature $+0,000000$ rainfall intensity $-0,000000$ humidity (no factors) \\
\hline & Red/ yellow leaves & $125-1,05$ temperature $+0,0036$ rainfall intensity $-1,13$ humidity (humidity) \\
\hline & Flower buds & $-27+1,32$ temperature $+0,0216$ rainfall intensity $-0,006$ humidity (rainfall intensity) \\
\hline & Flowering & $-51+0,67$ temperature $+0,0220$ rainfall intensity $+0,52$ humidity (rainfall intensity) \\
\hline & Young fruits & $\begin{array}{l}-89+5,30 \text { temperature }+0,0364 \text { rainfall intensity }-0,60 \text { humidity (temperature and rainfall inten- } \\
\text { sity) }\end{array}$ \\
\hline & Immature fruits & $-119+2,02$ temperature $+0,0187$ rainfall intensity $+0,971$ humidity (humidity) \\
\hline & Ripe fruits & $\begin{array}{l}-51,1+0,18 \text { temperature }+0,0201 \text { rainfall intensity }+0,633 \text { humidity (rainfall intensity and humid- } \\
\text { ity) }\end{array}$ \\
\hline \multirow{8}{*}{ A. montana } & Immature leaves & $7-0,46$ temperature $-0,0418$ rainfall intensity $+0,263$ humidity (rainfall intensity) \\
\hline & Mature leaves & $\begin{array}{l}96+2,18 \text { temperature }+0,0328 \text { rainfall intensity }-0,999 \text { humidity (rainfall intensity and humid- } \\
\text { ity) }\end{array}$ \\
\hline & Red/ yellow leaves & $59-2,88$ temperature $+0,0083$ rainfall intensity $+0,334$ humidity (temperature and humidity) \\
\hline & Flower buds & $16,2-0,182$ temperature $-0,00027$ rainfall intensity $-0,139$ humidity (humidity) \\
\hline & Flowering & $16,2-0,182$ temperature $-0,00027$ rainfall intensity $-00,139$ humidity (humidity) \\
\hline & Young fruits & $32,2+0,03$ temperature $+0,0010$ rainfall intensity $-0,393$ humidity (humidity) \\
\hline & Immature fruits & $-60,6+2,32$ temperature $+0,0043$ rainfall intensity $+0,045$ humidity (no factors) \\
\hline & Ripe fruits & $2,7+0,34$ temperature $+0,0115$ rainfall intensity $-0,145$ humidity (rainfall intensity) \\
\hline \multirow{8}{*}{ A. muricata } & Immature leaves & $-102+2,96$ temperature $-0,0389$ rainfall intensity $+0,626$ humidity (rainfall intensity) \\
\hline & Mature leaves & $118-0,73$ temperature $+0,0150$ rainfall intensity $-0,198$ humidity (rainfall intensity) \\
\hline & Red/ yellow leaves & $5,9+1,82$ temperature $+0,0056$ rainfall intensity $-0,582$ humidity (temperature and humidity) \\
\hline & Flower buds & $41,8-0,16$ temperature $+0,0121$ rainfall intensity $-0,387$ humidity (no factors) \\
\hline & Flowering & $79,4-1,04$ temperature $+0,0169$ rainfall intensity $-0,596$ humidity (no factors) \\
\hline & Young fruits & $8+0,47$ temperature $+0,0543$ rainfall intensity $-0,25$ humidity (rainfall intensity) \\
\hline & Immature fruits & $-164-0,82$ temperature $-0,0065$ rainfall intensity $+2,70$ humidity (humidity) \\
\hline & Ripe fruits & $-1,86-0,13$ temperature $-0,0036$ rainfall intensity $+0,358$ humidity (no factors) \\
\hline \multirow{8}{*}{ A. squamosa } & Immature leaves & $55,3+3,54$ temperature $+0,0232$ rainfall intensity $-1,86$ humidity (all factors) \\
\hline & Mature leaves & $-21,2+1,17$ temperature $-0,00643$ rainfall intensity $+0,999$ humidity (humidity) \\
\hline & Red/ yellow leaves & $173-3,91$ temperature $-0,0202$ rainfall intensity $-0,713$ humidity (all factors) \\
\hline & Flower buds & $-29,3+480$ temperature $-0,0006$ rainfall intensity $-1,19$ humidity (temperature and humidity) \\
\hline & Flowering & $\begin{array}{l}-89,5+4,01 \text { temperature }-0,00450 \text { rainfall intensity }-0,169 \text { humidity (temperature and rainfall } \\
\text { intensity) }\end{array}$ \\
\hline & Young fruits & $-11,5+1,72$ temperature $+0,0041$ rainfall intensity $-0,427$ humidity (temperature and humidity) \\
\hline & Immature fruits & $\begin{array}{l}-256+7,41 \text { temperature }+0,0238 \text { rainfall intensity }+0,85 \text { humidity (temperature and rainfall in- } \\
\text { tensity) }\end{array}$ \\
\hline & Ripe fruits & $-149+3,30$ temperature $-0,0075$ rainfall intensity $+0,844$ humidity (temperature and humidity) \\
\hline
\end{tabular}




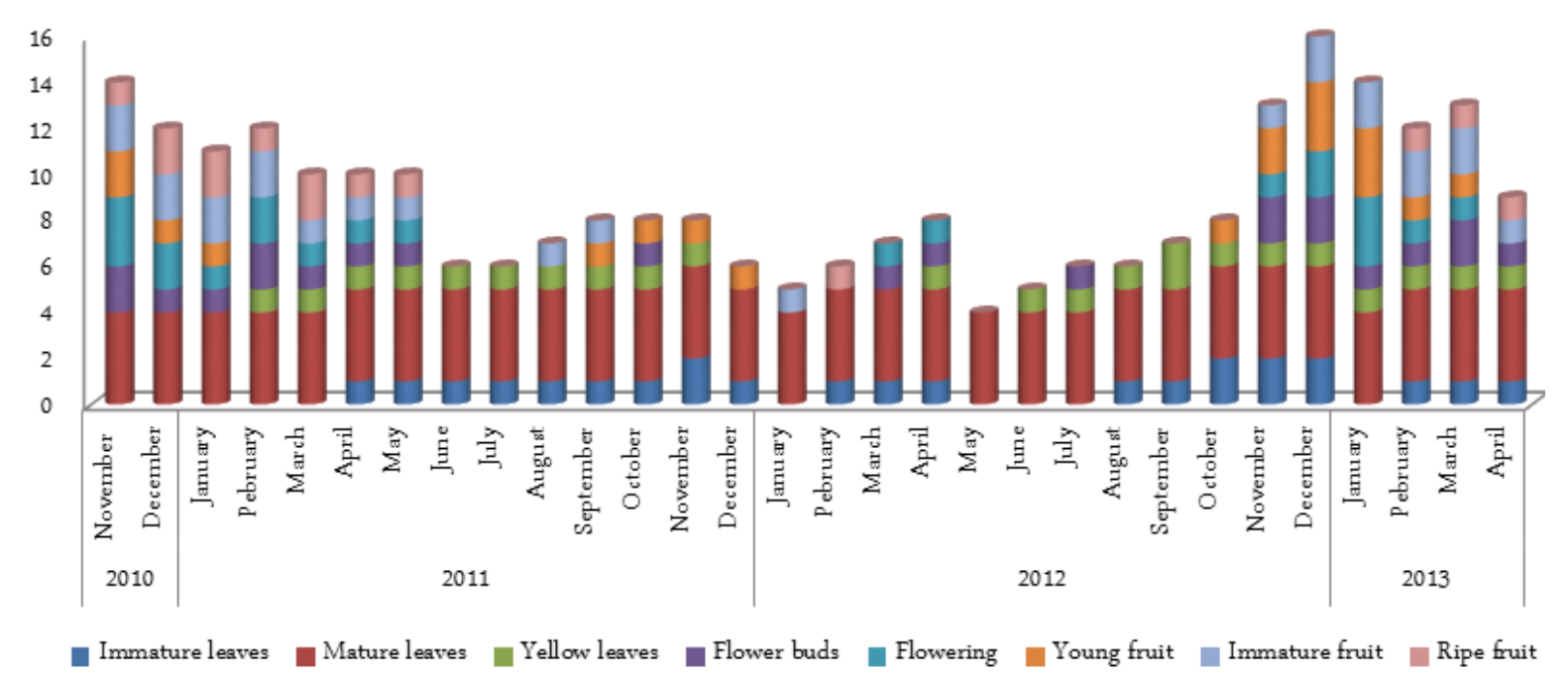

Figure 1. Proportion of shoots on the Annona glabra flowering and fruiting times

that has bad drainage. Two important climatic factors are rain and strong winds. Both, when they occur in high intensity and during flowering, greatly reduce pollination. Principally, rain factor happened when out of season [13,14].

Temperature $\left(25,56-28,33^{\circ} \mathrm{C}\right)$ and humidity $(66,83-$ $85,02 \%)$ become the most influential factor to flowering and fruiting time on $A$. squamosa, and recorded one a year during the wet month. Each derivation of $1^{\circ} \mathrm{C}$ temperature will increase flower buds as much as $480 \%$. Each derivation of $1 \mathrm{~mm}$ rainfall intensity will reduce flower buds of $A$. squamosa as much as $0,0006 \%$ and $0,00075 \%$ for ripe fruit. Each derivation of $1 \%$ humidity will reduce flower buds as much as $1,19 \%$. Each derivation of $1^{\circ} \mathrm{C}$ temperature will increase young fruit as much as $1,72 \%$. Each derivation of $1 \mathrm{~mm}$ rainfall intensity will increase the young fruit of $A$. squamosa as much as $0,0041 \%$, and derivation $1 \%$ humidity will reduce young fruit of it as much as $0,427 \%$. Each derivation of $1^{\circ} \mathrm{C}$ temperature will increase the ripe fruit of $A$. squamosa as much as $3,30 \%$. Then, each derivation of $1 \%$ humidity will increase the ripe fruit of $A$. squamosa as much as $0,844 \%$. Figure 1 show that vegetative growth on $A$. glabra is evergreenness (evergreen (with continuous defoliation)). The mature leaves are present (rank 4-5) throughout the year while senescent leaves are usually present at Rank 2. According to Department of Employment, Economic Development and Innovation of Queensland [15], $A$. glabra is a semi-deciduous tree. This is likely due to significant differences in the season, so the effect on the vegetative growth of $A$. glabra. Patterns of stem

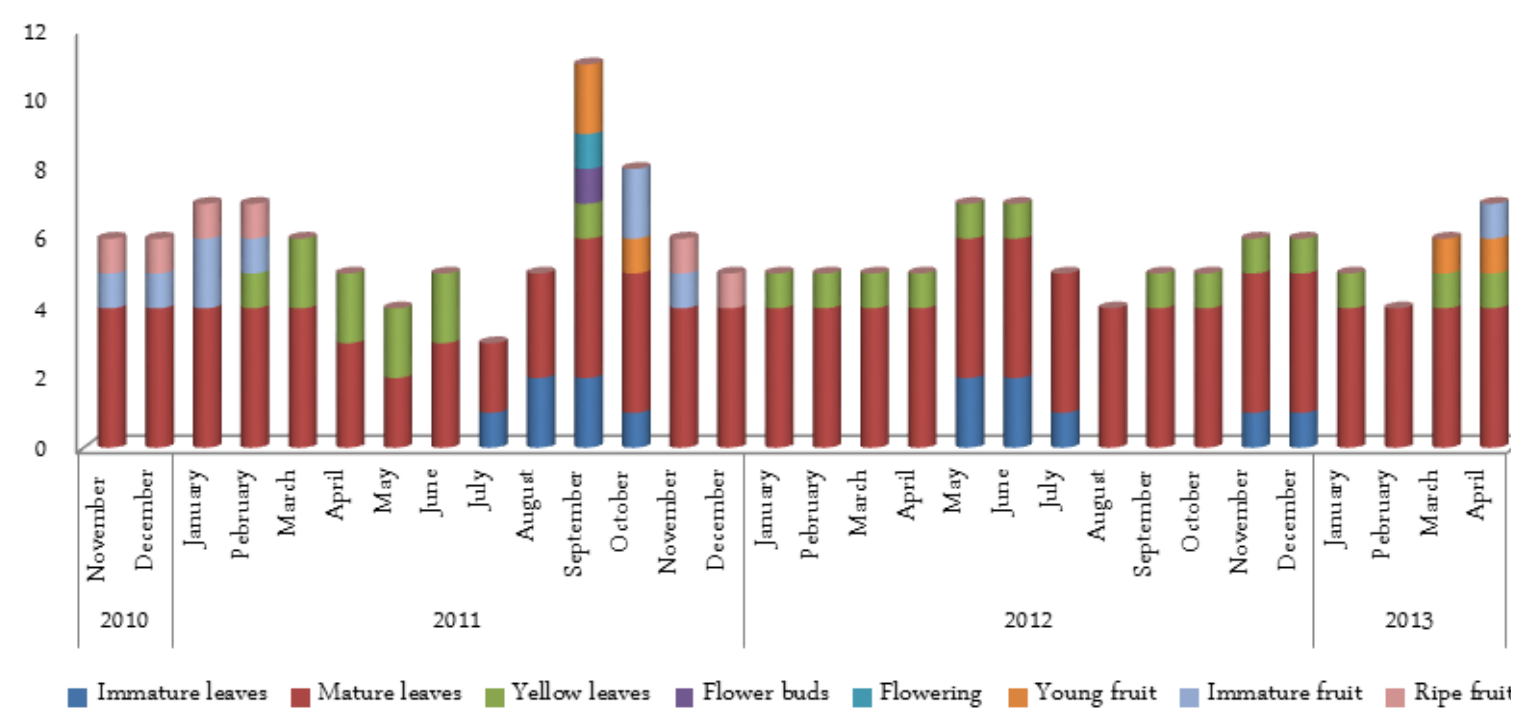

Figure 2. Proportion of shoots on the Annona montana flowering and fruiting times 


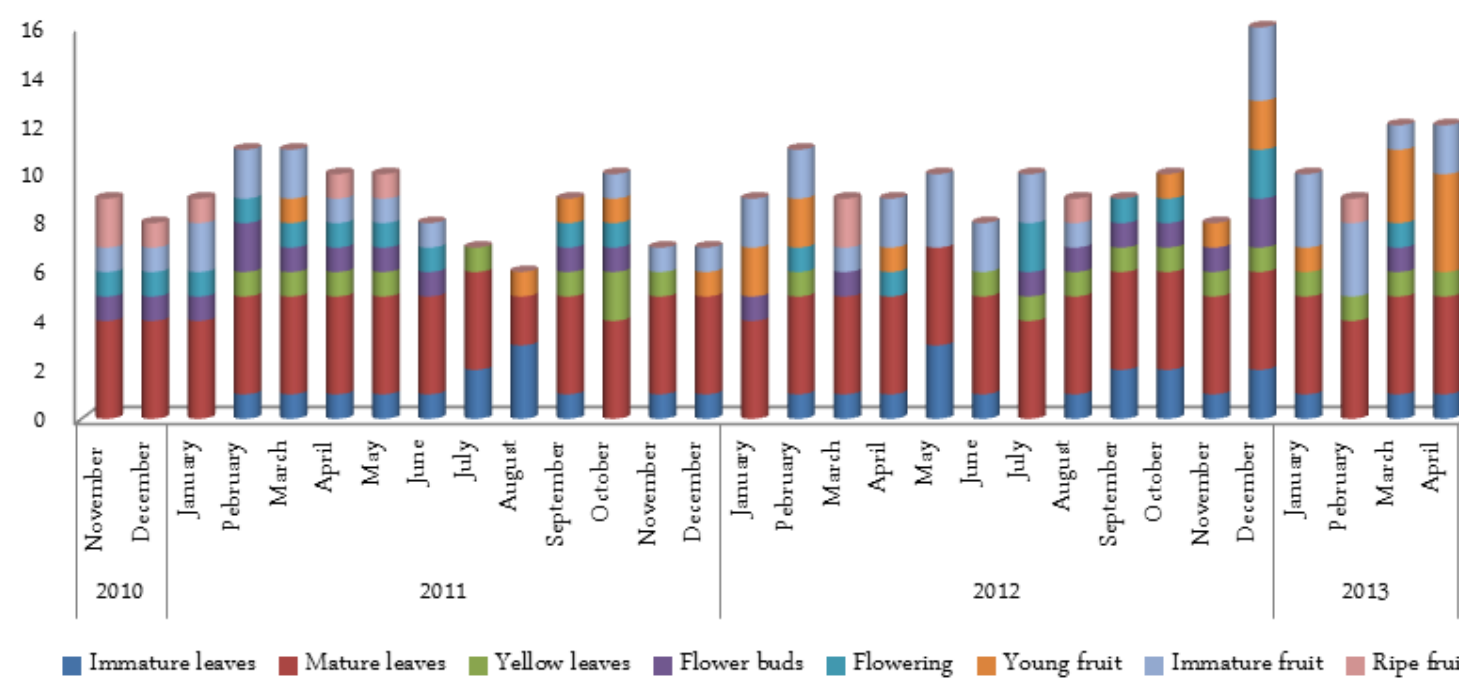

Figure 3. Proportion of shoots on the Annona muricata flowering and fruiting times

elongation is continuous growth (semicontinuous growth); stem elongation keeps rank 4 or 5 more than consecutive four months or 6 months in total. With seasonal synchronism is low synchronism (more than $50 \%$ of stem elongating periods occurs at the same time of the year. Flowering frequency on $A$. glabra is more than 4 to 5 times at rank 2 to 5 , that is $A$. glabra is flowering on rank 2 to 5 occurs more than 4 to 5 times every year. Flowering period from rainy to the early dry season. Based on observation, A. glabra occurs three times a year in wet and dry. The seasonal synchronism of flowering is high synchronism; that is more than $80 \%$ of flowering periods occurs at the same time of the year. Ripe fruits present during the period of investigations, which is fruiting twice a year in the same month.
The main flowering period in the wet tropics is from December to February with fruit formation following in January to March. The fruit falls from the trees and matures on the ground in February to April. Sporadic flowering and fruiting can also occur at other times of the year $[11,15]$. The fruit form over summer and autumn. Leaves of mature trees turn yellow and fall in the dry season. Germination peaks after rainfall and requires a period of temperatures above $25^{\circ} \mathrm{C}$. The general pattern of growth (flowering in January - February, December; Fruit formation on January - March; Fruit drop on February - April; Leaf fall from August - November. However, growth pattern in suitable conditions are flowering in March and November; Fruit formation on April and December; Fruit drop on January and May [16]. Different from A. glabra, the

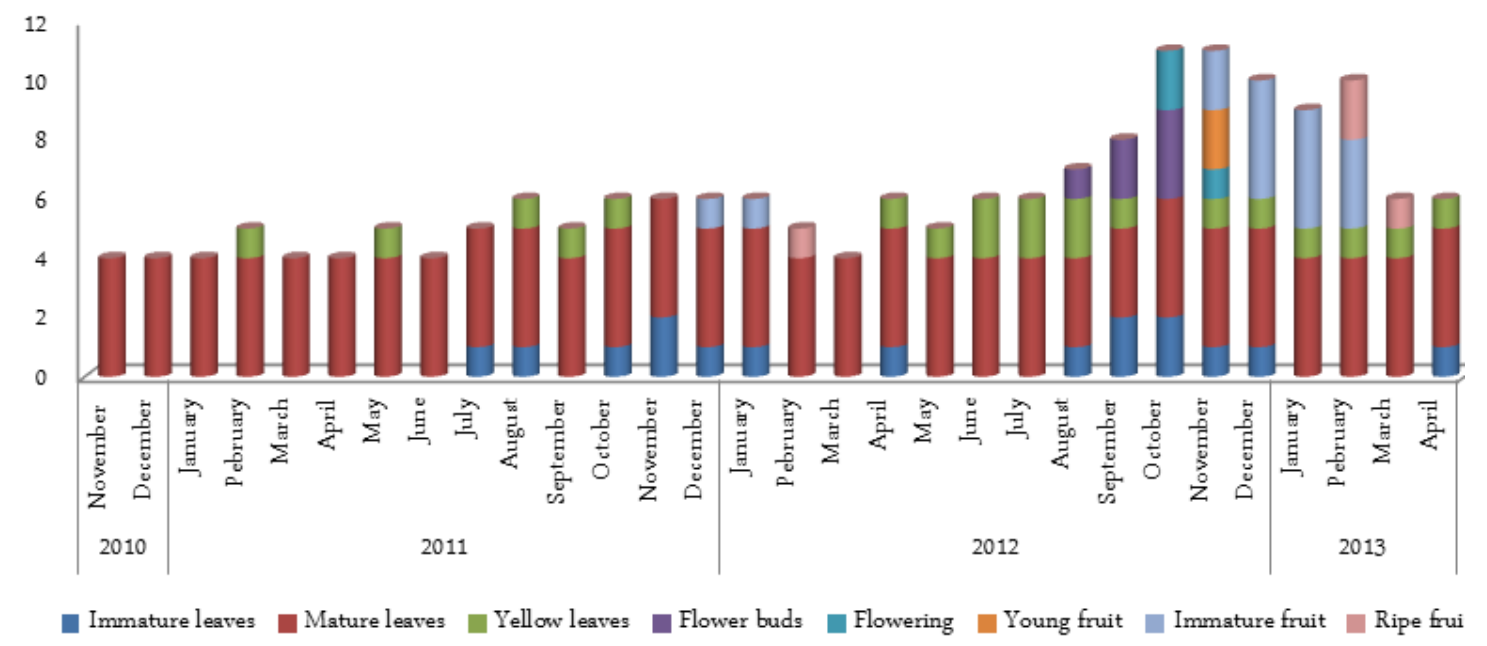

Figure 4. Proportion of shoots on the Annona squamosa flowering and fruiting times 
Table 3. Comparison of flowering and fruiting time on four species of Annona based on phenological categories [10].

\begin{tabular}{|c|c|c|c|c|c|}
\hline \multirow{2}{*}{ Growth } & \multirow{2}{*}{ Phenological categories } & \multicolumn{4}{|c|}{ Four species of Annona } \\
\hline & & A. glabra & A. montana & A. muricata & A. squamosa \\
\hline \multirow[t]{3}{*}{ Vegetative } & Evergreens & $\begin{array}{l}\text { Evergreen (with } \\
\text { continuous } \\
\text { defoliation) }\end{array}$ & Semi-evergreen & $\begin{array}{l}\text { Evergreen (with } \\
\text { continuous } \\
\text { defoliation) }\end{array}$ & $\begin{array}{l}\text { Evergreen (with } \\
\text { seasonal defoliation) }\end{array}$ \\
\hline & $\begin{array}{l}\text { Patterns of stem } \\
\text { elongation }\end{array}$ & $\begin{array}{l}\text { Semicontinuous } \\
\text { growth }\end{array}$ & $\begin{array}{l}\text { Rhythmic growth } \\
\text { with } 1 \text { peak }\end{array}$ & Continuous growth & $\begin{array}{l}\text { Rhythmic growth with } \\
2-3 \text { peaks }\end{array}$ \\
\hline & $\begin{array}{l}\text { Seasonal synchronism } \\
\text { of stem elongation }\end{array}$ & Low synchronism & $\begin{array}{l}\text { Non synchroni- } \\
\text { zation }\end{array}$ & High synchronism & High synchronism \\
\hline \multirow[t]{4}{*}{ Reproductive } & Flowering frequency & $\begin{array}{l}\text { More than } 4 \text { to } 5 \\
\text { times at rank } 2 \text { to } 5\end{array}$ & $\begin{array}{l}1 \text { to } 3 \text { times at } \\
\text { rank } 2 \text { to } 3\end{array}$ & $\begin{array}{l}\text { Continuous } \\
\text { flowering at rank } 2 \\
\text { to } 5\end{array}$ & $\begin{array}{l}1 \text { to } 3 \text { times at rank } 2 \\
\text { to } 3\end{array}$ \\
\hline & Flowering period & $\begin{array}{l}\text { From rainy to the } \\
\text { early dry season }\end{array}$ & Dry season & $\begin{array}{l}\text { Throughout the } \\
\text { year }\end{array}$ & Rainy season \\
\hline & $\begin{array}{l}\text { Seasonal synchronism } \\
\text { of flowering }\end{array}$ & High synchronism & $\begin{array}{l}\text { Non synchroni- } \\
\text { zation }\end{array}$ & Low synchronism & Non synchronization \\
\hline & Fruiting & Ripe fruits present & $\begin{array}{l}\text { Ripe fruits } \\
\text { present }\end{array}$ & Ripe fruits present & Ripe fruits present \\
\hline
\end{tabular}

vegetative growth of $A$. montana is semievergreen. This condition is about evergreen, but the amount of mature leaves occasionally decrease to rank 2 or 3 with patterns of stem elongation is rhythmic growth with 1 peak. One peak is that elongation occurs once a year, and the resting period extends over half a year or longer. However, seasonal synchronism of $A$. montana stem elongation is non-synchronization, that is stem elongation periods in a calendar year are a variable year by year. Flowering frequency of $A$. montana is 1 to 3 times at rank 2 to 3 , that is flowering (rank 2-3) occurs 1 to 3 times every year with a flowering period during dry season. Seasonal synchronism of flowering is non-synchronization (flowering periods in a calendar year are a variable year by year). Ripe fruits present during observations is recorded once a year during the wet month.

Based on [17], A. montana flowering on October until December. However, during the period of investigation, A. montana is flowering to September. Differences in flowering time are not too far probably influenced by climatic factors that differ between the tropical and sub-tropical climates. In the area with the extreme seasonal cycle, the climate has been a very influential factor for plant growth and development, especially in the phase of flowering and fruiting plant. Whereas, in the weakly seasonal area, climatic factors must have less influence on the phenological phases than in strongly seasonal ones [18]. Vegetative growth of $A$. muricata is evergreen (with continuous defolia- tion). This fact is same with $A$. glabra that the pattern of the stem elongating is continuous growth (most of shoots (rank 4 or 5) continue to elongate nearly throughout the year (more than ten months). Then, with seasonal synchronism of stem elongation is high synchronism (more than $80 \%$ of stem elongating periods occurs at the same time of the year). Flowering frequency of $A$. muricata is continuous flowering at rank 2 to 5 (continuous flowering (rank 2-5) throughout the year). Flowering period throughout the year (continuously flowering throughout the year) and seasonal synchronism of flowering is low synchronism (more than $50 \%$ of flowering periods occurs at the same time of the year). Ripe fruits present and fruiting twice a year in wet.

This species is adapted to areas of high humidity and relatively warm winters; temperatures below $5^{\circ} \mathrm{C}$ will cause damage to leaves and small branches, and temperatures below $3^{\circ} \mathrm{C}$ can be fatal. The fruit becomes dry and is no longer suitable for concentrate. Leaf fall happened in all soursop cultivars in May and June (after harvest) and September and October (dry season). Flowering occurs during the rainy season, with extremes in February and July. Fruit development was expressive from December to March [19]. Figure 4 show that the vegetative growth of $A$. squamosa is evergreen (with seasonal defoliation). The condition about mature leaves that are usually present (rank 4-5) throughout the year, while senescent leaves reach rank 2 or 3 . The pattern of stem elongation is rhythmic 
growth with 2-3 peaks, that is elongation occurs two or three times per year at regular intervals. Seasonal synchronism of stem elongation same with $A$. muricata. Flowering frequency on $A$. squamosa is 1 to 3 times at rank 2 to 3; that is flowering (rank 2-3) occurs 1 to 3 times every year. A flowering period occurs during rainy season; based observation occurs from October until January. Seasonal synchronism of flowering on A. squamosa is non-synchronization (flowering periods in a calendar year are a variable year by year. Ripe fruits present in February until March (wet month). $A$. squamosa recorded one a year during the wet month of flowering and fruiting.

Flowering and fruiting In Puerto Rico and the Virgin Islands occur throughout the year. In India, the leaves of $A$. squamosa fall in January to February and are renewed in April to May when the flowers appear. Fruiting of $A$. squamosa is in July to August. Flowering occurs gradually over many months, so harvest time is spread over a period of months also [2,20].

Comparison of flowering and fruiting times on four species of Annona can be seen on the Table 3.

\section{CONCLUSIONS}

Humidity was the most affected climate factors on the flowering and fruiting times of those species. Specifically, rainfall intensity $(0-550 \mathrm{~mm})$ affected to Annona muricata, temperature $\left(25,56-28,33{ }^{\circ} \mathrm{C}\right)$ and humidity $(66,83-85,02 \%)$ to Annona squamosa, and humidity to $A$. glabra $(71,62-85,02 \%)$ and $A$. montana (71,62 to $82,94 \%)$ as well. Flowering time of $A$. glabra occurs three times a year in wet and dry season. Fruiting time occurs twice a year in the same month. Annona muricata flowering throughout the year and fruiting twice a year in wet, while $A$. montana and $A$. squamosa recorded one a year during the wet month.

\section{REFERENCES}

1. Scheldeman X (2002) Distribution and potential of cherimoya (Annona cherimola Mill.) and highland papayas (Vasconcellea spp.) in Ecuador. Thesis. Faculty of Agricultural and Applied Biological Sciences. Department Plant Production. Belgium.

2. Pinto AC, de Q, Jackson D (2006) Annona: Annona cherimola, Annona muricata, A. reticulata, A. senegalensis and $A$. squamosa. Field Manual for Extension Workers and Farmers. University of Southampton, UK.

3. Luciana S, Tavares JF, da Silva MS, Falcão EV, de Morais e Silva L, da Silva Soares GC, Scotti MT (2012) Chemotaxonomy of three genera of the annonaceae famly using self-organizing maps and 13C NMR data of diterp- enes. Quim. Nova. 35(11). http://dx.doi.org/10.1590/S0 100-40422012001100008.

4. Putri DMS (2011) Phenology of Rhododendron spp. (Subgenus Vireya) collection of Eka Karya Botanic Garden Bali. J. Hort. 21(3): 232-244.

5. Prive JP, Sullivan JA, Proctor JTA, Allen OB (1993) Climate influences vegetative and reproductive components of Primocane-fruiting Red Raspberry Cultivars. J. Amer. Soc. Hort. Sci. 118(3): 393-399.

6. Hamann A (2004) Flowering and fruiting phenology of a Philippine submontane rainforest: climatic factors as proximate and ultimate causes. Journal of Ecology. 92: 2431.

7. Sakai S, Momose K, Yumoto T, Nagamitsu T, Nagamasu H, Hamid AA, Nakashizuka T (1999) Plant reproductive phenology over four years including an episode of general flowering in lowland dipterocarp forest, Sarawak, Malaysia. American Journal of Botany. 86(10): 1414-1436.

8. Van Schaik CP, Terborgh JW, Wright SJ (1993) The phenology of tropical forests: adaptive significance and consequences for primary consumers. Annual Review of Ecological Systematics. 24: 353-377 in Hamann A (2004) Flowering and fruiting phenology of a Philippine submontane rainforest: climatic factors as proximate and ultimate causes. Journal of Ecology. 92: 24-31.

9. Frankie GW, Baker HG, Opler PA (2013) Comparative phenological studies of trees in tropical wet and dry forests in the lowlands of Costa Rica. JSTOR. 881-920.

10. Hatta H, Darnaedi D (2005) Phenology and growth habits of tropical trees: long-term observations in the Bogor and Cibodas Botanic Gardens, Indonesia. National Science Museum Tokyo. Japan. 436 p. (pp. 21-26).

11. Doak A (2006) Control methods and case studies: Pond Apple Annona glabra (Annonaceae) management. Department of Natural Resources, Mines and Water. Brisbane. p. 5-6.

12. Zimmerman JK, Wright SJ, Calderon O, Pagan MA and Paton S (2007). Flowering and fruiting phenologies of seasonal and aseasonal neotropical forests: the role of annual changes in irradiance. Journal of Tropical Ecology. 23: 231- 251.

13. Nakasone HY, Paull RE (1998). Tropical fruits. CAB International. London. p. 45-75.

14. Indriyani NLP (2012) The growth evaluation of two Annona species at seedling phase. ARPN Journal of Agricultural and Biological Science. 7(7): 541-544.

15. Department of Employment, Economic Development and Innovation of Queensland (2011) Annona glabra: Pond Apple. Fact sheet od Declared Class of Pest Plant. Page 14. www.daff.qld.gov.au. Accessed date: August 20 ${ }^{\text {th }}, 2013$.

16. Weed Management Guide (2003) Pond apple (Annona 
glabra). Weeds of National Significance. www.weeds.org.au Accessed date: August 20 2013.

17. Gottsberger G (1989). Beetle pollination and flowering rhythm of Annona spp. (Annonaceae) in Brazil. Pl. Syst. Evol. 167: 165-187.

18. de Medeiros DPW, Lopes AV, Zickel CS (2007) Phenology of woody species in tropical coastal vegetation, northeastern Brazil. Flora. 202: 513-520.
19. do Nascimento TB, Filho ABG, dos Santos JDA (2002) Fenologia da gravioleira (Annona muricata) em area de cerrado do amapa, Brasil. Acta Amazonica. 32(3): 367-376.

20. Orwa C, Mutua A, Kindt R, Jamnadass R, Anthony S (2009) Annona squamosa. Agroforestree Database: a tree reference and selection guide version 4.0. http://www.worldagroforestry.org/sites/treedbs/treedatabases.asp. Accessed date: November 21 ${ }^{\text {st }}$, 2013. 